\title{
Generation of GGTA1 biallelic knockout pigs via zinc-finger nucleases and somatic cell nuclear transfer
}

\author{
BAO Lei ${ }^{1,2 \dagger}$, CHEN HaiDe ${ }^{1 \dagger}$, JONG UiMyong ${ }^{1,3 \dagger}$, RIM CholHo ${ }^{1,3 \dagger}$, LI WenLing ${ }^{1}$, \\ LIN XiJuan ${ }^{1}$, ZHANG Dan ${ }^{4,5}$, LUO Qiong ${ }^{6}$, CUI Chun ${ }^{1}$, HUANG HeFeng ${ }^{4,5,7}$, ZHANG Yan ${ }^{8}$, \\ XIAO Lei ${ }^{1} \&$ FU ZhiXin ${ }^{1,2,8,9 *}$ \\ ${ }^{1}$ College of Animal Sciences, School of Medicine, Zhejiang University, Hangzhou 310058, China; \\ ${ }^{2}$ Institute of Biochemistry and Cell Biology, Shanghai Institutes for Biological Sciences, Chinese Academy of Sciences, Shanghai 200031, \\ China; \\ ${ }^{3}$ Department of Animal Cloning, Cloning Research Center, Biotechnology Branch, Academy of Sciences, Pyongyang, the Democratic People's \\ Republic of Korea; \\ ${ }^{4}$ Department of Reproductive Endocrinology, Women's Hospital, School of Medicine, Zhejiang University, Hangzhou 310058, China; \\ ${ }^{5}$ Key Laboratory of Reproductive Genetics, Zhejiang University, Ministry of Education, Hangzhou 310006, China; \\ ${ }^{6}$ Department of Reproductive Genetics, Women's Hospital, School of Medicine, Zhejiang University, Hangzhou 310006, China; \\ ${ }^{7}$ Department of Obstetrics, Women's Hospital, School of Medicine, Zhejiang University, Hangzhou 310006, China; \\ ${ }^{8}$ Institut Pasteur of Shanghai, Shanghai Institutes for Biological Sciences, Chinese Academy of Sciences, Shanghai 200031, China; \\ ${ }^{9}$ College of Animal Science and Technology, Hebei Normal University of Science and Technology, Changli 066600, China
}

Received August 12, 2013; accepted October 11, 2013; published online January 14, 2014

\begin{abstract}
Genetically modified pigs are valuable models of human disease and donors of xenotransplanted organs. Conventional gene targeting in pig somatic cells is extremely inefficient. Zinc-finger nuclease (ZFN) technology has been shown to be a powerful tool for efficiently inducing mutations in the genome. However, ZFN-mediated targeting in pigs has rarely been achieved. Here, we used ZFNs to knock out the porcine $\alpha$-1,3-galactosyl-transferase (GGTA1) gene, which generates Gal epitopes that trigger hyperacute immune rejection in pig-to-human transplantation. Primary pig fibroblasts were transfected with ZFNs targeting the coding region of GGTA1. Eighteen mono-allelic and four biallelic knockout cell clones were obtained after drug selection with efficiencies of $23.4 \%$ and $5.2 \%$, respectively. The biallelic cells were used to produce cloned pigs via somatic cell nuclear transfer (SCNT). Three GGTAl null piglets were born, and one knockout primary fibroblast cell line was established from a cloned fetus. Gal epitopes on GGTAl null pig cells were completely eliminated from the cell membrane. Functionally, GGTA1 knockout cells were protected from complement-mediated immune attacks when incubated with human serum. This study demonstrated that ZFN is an efficient tool in creating gene-modified pigs. GGTAl null pigs and GGTAl null fetal fibroblasts would benefit research and pig-to-human transplantation.
\end{abstract}

pig, xenotransplantation, ZFNs, GGTA1, biallelic knockout, SCNT

Citation: Bao L, Chen HD, Jong UM, Rim CH, Li WL, Lin XJ, Zhang D, Luo Q, Cui C, Huang HF, Zhang Y, Xiao L, Fu ZX. Generation of GGTAl biallelic knockout pigs via zinc-finger nucleases and somatic cell nuclear transfer. Sci China Life Sci, 2014, 57: 263-268, doi: 10.1007/s11427-013-4601-2

Pigs are considered to be one of the best species to generate models of human disease and provide organs for xenotrans-

$\dagger$ Contributed equally to this work

*Corresponding author (email: fzxlj1@163.com) plantation [1]. Genetically modified pigs have been demonstrated to successfully mimic human disease symptoms as well as to reduce immune rejection in pig-to-human transplantation [2-4]. However, traditional gene targeting using 
homologous recombination (HR) has only been shown to be efficient in embryonic stem (ES) cells [5,6]. Unfortunately, to date, authentic pig ES cell lines have not been established. HR in cultured somatic cells is extremely inefficient, and this has become the main barrier in making gene-targeted pigs $[3,7,8]$. Recently, zinc-finger nuclease (ZFN) technology was shown to be a revolutionary tool for introducing targeted modifications into the genome.

Xenotransplantation is a potential approach to resolve the problem of human graft shortages in clinical allotransplantation. Thus far, pigs are the most appropriate animals for organ donation because of their compatible size and physiological characteristics with humans.

The cell membrane of most mammals presents $\alpha-1$, 3-galactosyl (Gal) epitopes, with the exception of humans and Old World monkeys [9]. However, there are anti-Gal antibodies in human blood. Therefore, transplantation of pig organs into humans causes a hyperacute rejection response, which is a major barrier for pig-to-human transplantation [10-12]. Gal epitopes are catalyzed by $\alpha-1,3$-galactosyltransferase (GGTA1). Therefore, to eliminate the xenoantigen, the pig GGTAl gene has been knocked out using conventional methods $[8,13]$. Furthermore, solid organs from GGTAl knockout pigs displayed significantly improved survival in pig-to-baboon xenotransplantation experiments $[2,4]$. However, HR technology has low efficiency and introduces exogenous drug resistance genes.

Here, we report the generation of GGTA1 null pigs using ZFN technology.

\section{Materials and methods}

\subsection{Generation of zinc-finger nucleases}

The ZFN expression plasmids were obtained from Sigma Aldrich, USA. A total of three pairs of ZFNs targeting exon 4 and exon 6 of the porcine GGTAl gene were designed and screened for activity in a yeast MEL-1 reporter assay. Initial activity evaluation of ZFNs in mammalian cells was performed using induced pluripotent stem (iPS) cells of pigs that were generated previously [14]. Pig iPS cells $\left(5 \times 10^{5}\right)$ were transfected with each pair of ZFN plasmids together with a plasmid carrying a puromycin resistance cassette using the FuGene HD transfection reagent (Roche, Switzerland). After selection with $1 \mu \mathrm{g} \mathrm{mL} \mathrm{m}^{-1}$ puromycin (Sigma, USA) for $3 \mathrm{~d}$, the surviving cells were harvested and assayed by PCR of the GGTAl locus with primers flanking the targeting sites. The PCR product was subcloned into the pEASY-Blunt Cloning Vector (Transgene, China) in accordance with the manufacturer's protocol. For each ZFN set, 50 colonies were picked and sequenced with the M13F primer. The targeting frequency was calculated as follows: mutant cell $\%=($ number of mutant colonies $/ 50) \times 100 \% \times 2$.

\subsection{Cell culture, transfection and selection}

Fetal fibroblasts were isolated from porcine fetuses on day 35 of gestation as previously described and cultured for three passages in Dulbecco's Modified Eagle Medium (DMEM; GIBCO, USA) supplemented with $1 \%$ nonessential amino acids (GIBCO), $2 \mathrm{mmol} \mathrm{L}^{-1} \mathrm{~L}$-glutamine (Sigma), 0.1 mmol L $\mathrm{L}^{-1} \beta$-mercaptoethanol, $0.1 \mathrm{mmol} \mathrm{L}^{-1}$ sodium pyruvate (Sigma-Aldrich), and 15\% FBS (Hyclone, USA) before transfection. The cells were trypsinized $(0.25 \%$ Trypsin-EDTA, GIBCO), washed with DMEM, and finally suspended in $400 \mu \mathrm{L}$ transfection medium $(75 \%$ cytosalts $\left(120 \mathrm{mmol} \mathrm{L}{ }^{-1} \mathrm{KCl}, 0.15 \mathrm{mmol} \mathrm{L}{ }^{-1} \mathrm{CaCl}_{2}, 10 \mathrm{mmol} \mathrm{L}{ }^{-1}\right.$ $\mathrm{K}_{2} \mathrm{HPO}_{4}$; pH 7.6, $5 \mathrm{mmol} \mathrm{L}{ }^{-1} \mathrm{MgCl}_{2}$ ) and 25\% Opti-MEM (GIBCO)) containing $7.5 \mu \mathrm{g}$ of each Set\#2 ZFN plasmid and $5 \mu \mathrm{g}$ pCDNA3.1-GFP. Electroporation was performed at $300 \mathrm{~V}$ for a single $30-\mathrm{ms}$ pulse (ECM2001 Electro Cell Manipulator, BTX, USA) in a 2-mm gap cuvette (BTX) [15]. After electroporation, the cells were plated into five $10-\mathrm{cm}$ dishes (NUNC, Denmark) for $2 \mathrm{~d}$ of culture in DMEM supplemented with $15 \%$ FBS, followed by a 2-week selection with G418 $\left(500 \mu \mathrm{g} \mathrm{mL}^{-1}\right)$. Cell colonies were picked using $10 \mathrm{~mm} \times 10 \mathrm{~mm}$ cloning cylinders (Sig$\mathrm{ma}$ ), passaged, and detected via PCR genotyping.

\subsection{Somatic cell nuclear transfer and generation of cloned pigs}

Somatic cell nuclear transfer (SCNT) was performed as previously described [16]. Biallelic knockout fibroblasts were cultured to sub-confluence before nuclear transfer. NT embryos cultured for 20 or $40 \mathrm{~h}$ were surgically transferred into surrogates. Gestation was monitored weekly via ultrasound starting 24 days after transfer. Two pregnancies were aborted on day 35 of gestation to establish fetal fibroblast cell lines [17]. The deliveries were performed by cesarean section on day 116-120 of gestation. Ear tissue from the piglets was sampled for genotyping using the primers mentioned above. The PCR products were sequenced. Double curves in the sequence diagram usually indicate putative mutation.

\subsection{Off-target site prediction}

Off-targeting sites were searched by scanning the porcine genome using "The ZFN site," an online bioinformatic tool. The allowed spacing length was set at 5 or $6 \mathrm{bps}$, and two mismatches were permitted per half site of $\mathrm{ZFN}$.

\subsection{Isolectin staining}

A total of $1 \times 10^{5}$ fibroblasts from 11LW5, G65P2, and G3F1 were harvested, washed, and incubated in $0.5 \mathrm{~mL}$ PBS with $1.5 \mu \mathrm{g}$ FITC-conjugated isolectin-B4 (Enzo Life Sciences, Switzerland) for $5 \mathrm{~min}$ at $37^{\circ} \mathrm{C}$. Subsequently, the cells were washed with PBS three times, plated in a single well 
of a 48-well plate, and examined immediately by fluorescence microscopy.

\subsection{Complement-mediated lysis assay of porcine fibro- blasts}

An MTT assay and Trypan blue staining were performed to study the susceptibility of GGTAl null cells from cloned piglets and fetuses to lysis by the human complement system. Porcine fibroblasts $\left(2 \times 10^{5}\right)$ were incubated in PBS with $10 \%$ pooled complement-preserved normal human serum (derived from a healthy volunteer) for $6 \mathrm{~h}$. The treated cells were seeded onto a 96-well plate (NUNC) at $2 \times 10^{4}$ cells per well and cultured in DMEM supplemented with $15 \%$ FBS for $8 \mathrm{~h}$. An MTT Cell proliferation and cytotoxicity assay kit (Beyotime, China) was used to evaluate cell activity in accordance with the manufacturer's protocol. Soluble formazan accumulation was detected with a spectrophotometer (SpectraMax M5 Multi-Mode Microplate Readers, Molecular Devices, USA) at a wavelength of $570 \mathrm{~nm}$. Cell survival was calculated as follows: viable cell\% $=($ absorptivity of human serum treated cells/absorptivity of non-treated cells $) \times 100$. For the Trypan blue staining assays, Trypan blue solution (Beyotime) was added to the treated cell suspensions at a final concentration of $0.04 \%$. Three minutes later, both live and dead cells (stained as blue) were quantified and the mortality rate was calculated as follows: dead cell\%=(number of dead cells/number of total cells) $\times 100$.

\section{Results}

\subsection{Creation of GGTA1 mutated porcine cells}

Three pairs of ZFNs targeting the pig GGTAl coding region were obtained commercially from Sigma Aldrich (Figure 1A). The efficiency of the ZFNs was tested in pig iPS cells previously generated by our laboratory. Only two pairs (Set\#1 and Set\#2) showed DNA cleavage activity, with efficiencies of $4.0 \%$ and $22.2 \%$, respectively (Figure 1B). Therefore, the more active pair of ZFN (Set\#2) plasmids that recognized exon 6 of GGTAl was used to generate gene-targeted fibroblasts. ZFN plasmids together with pCDNA3.1-GFP plasmid were transfected into pig fetal fibroblasts via electroporation. After selection with G418, a total of 95 cell colonies were picked with cloning cylinders for further culture. Among them, 77 proliferated sufficiently and were therefore genotyped by sequencing the PCR product corresponding to the targeting site. We identified 18 clones carrying different mono-allelic mutations at the ZFN targeting site and four biallelic knockout cell clones (Figure $1 \mathrm{C}-\mathrm{E})$.

To address off-targeting events of the ZFNs, an online bioinformatics tool, "The ZFN-site," was used to predict potential off-targeting sites by searching the pig genome.
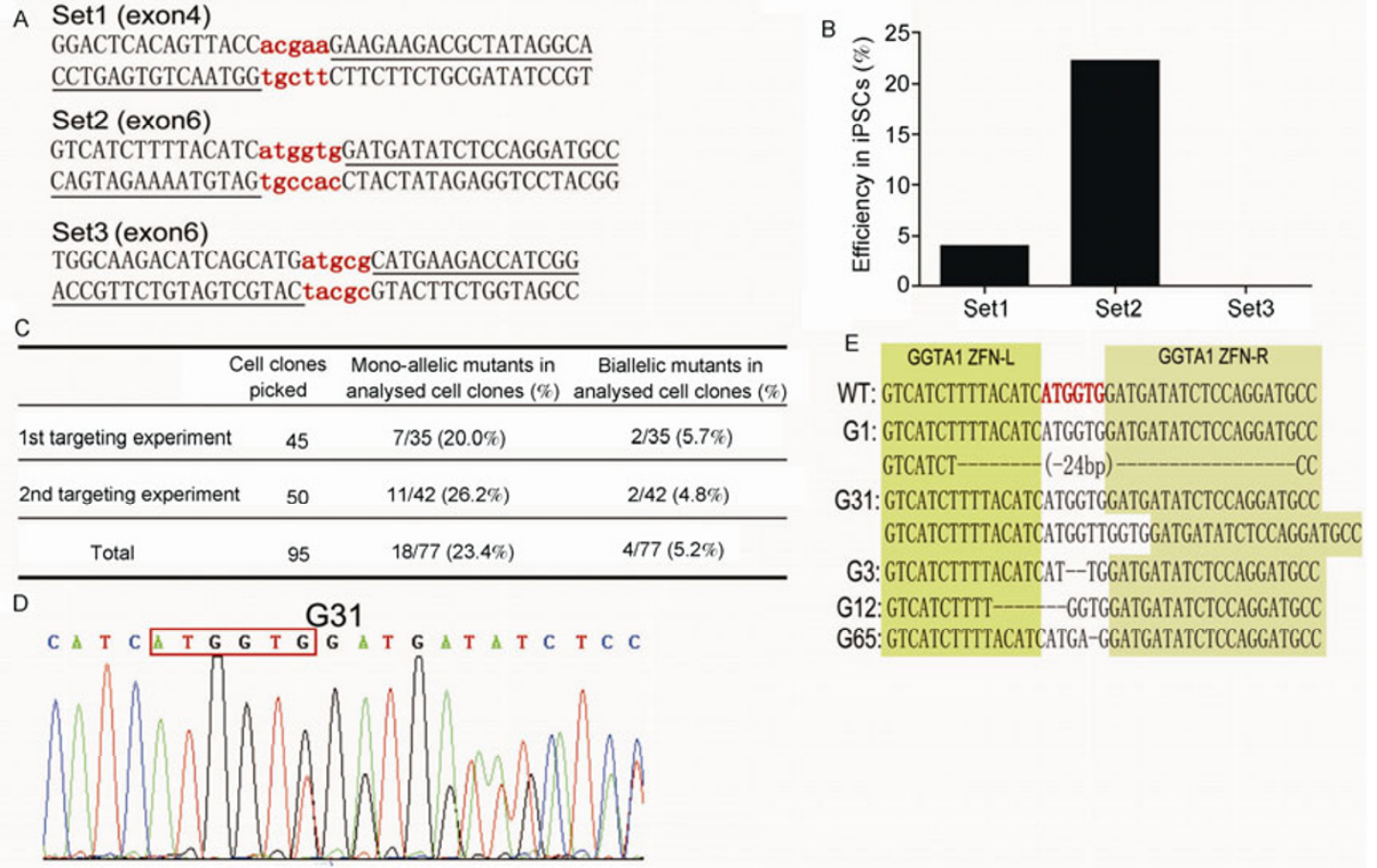

Figure 1 ZFN-mediated targeting in pig somatic cells. A, Binding sites (underlined) of the GGTA1 zinc-finger nucleases. B, Efficiency of three sets of ZFNs in pig iPS cells by sequencing analysis. C, Generation of GGTA1 mutant cell clones by ZFNs. D, Sequencing diagram of the mutant clone G31 with a mono-allelic 4-bp insertion at the ZFN-targeting site. Space between the two ZFN sites is indicated by a red rectangle. The diagram shows a double curve after the mutation site. E, Sequencing results of five GGTA1 mutant cell clones. G1 and G31 carry mono-allelic mutations. G3, G12, and G65 are all homologous biallelic knockout clones. 
Fortunately, no off-target sites were predicted with the permission of two mismatches per half-site of GGTA1 with ZFN Set\#2.

\subsection{Generation of GGTA1 knockout piglets by somatic cell nuclear transfer}

Three homozygous KO cell clones (G3, G12 and G65) (Figure 1E) were used as donor cells for SCNT. A total of 2093 cloned embryos were transferred into eleven surrogate mothers (Table 1). Eight pigs were confirmed pregnant by ultrasonography. Among them, one surrogate mother aborted the pregnancy for unknown reasons. Two were sacrificed, and the fetuses were removed to establish serial GGTAl knockout cell lines. The other five surrogate mothers gave birth to a total of 15 living piglets (Table 1). Sequence analysis revealed that only three piglets were knockout individuals, derived from cell clones G12 (one piglet) and G65 (two piglets) (Figure 2A and B). Unexpectedly, all nine piglets derived from cell clone G3 were not gene-modified. Therefore, we checked cell clone G3 for
SCNT and found that the overwhelming majority of cells that were originally mutated were replaced by wild-type cells (data not shown). It was speculated that after several passages of amplification, the wild-type cells mixed with the knockout clones and became the predominant population due to impaired proliferation of the knockout cells.

\subsection{Generation of fetal fibroblasts from GGTAI knockout fetuses}

It is generally considered that a pig requires multiple genetic modifications to be suitable for xenotransplantation. GGTA1 null mutants with modification of other immunerelated components would make pig organs much more compatible with human bodies [18-21]. However, initiallytargeted fibroblasts nearly exhaust their proliferative capacity due to the long time required for drug selection and amplification. Therefore, it is necessary to obtain strongly proliferative GGTA1 null somatic cells from fetuses. In our study, two pregnant surrogate mothers were killed at day 35 (Table 1), and nine morphologically normal fetuses (G3F1-

Table 1 Cloning results using ZFN modified GGTA1 null cells with number of transferred embryos, pregnant sows, liveborn and mutant piglets

\begin{tabular}{|c|c|c|c|c|c|}
\hline Surrogate & Donor cell line & Transferred NT embryos & Pregnant & Liveborn & Mutant piglets \\
\hline 0412 & G3 & 235 & Aborted & - & - \\
\hline 0420-1 & G3 & 177 & \multicolumn{2}{|c|}{ Fetus removed on day 35} & 1 (killed fetus) \\
\hline 0420-2 & G3 & 185 & \multicolumn{2}{|c|}{ Fetus removed on day 35} & 0 \\
\hline $0422-1$ & G3 & 191 & - & - & - \\
\hline $0422-2$ & G3 & 199 & - & - & - \\
\hline $0427-1$ & G12 & 194 & Delivered & 1 & 1 \\
\hline 0427-2 & G12 & 201 & Delivered & 3 & 0 \\
\hline 0506-1 & G3 & 192 & Delivered & 6 & 0 \\
\hline $0506-2$ & G3 & 192 & - & - & - \\
\hline $0608-1$ & G65 & 157 & Delivered & 2 & 2 \\
\hline Total $(n=11)$ & & 2093 & $\begin{array}{c}8 / 11=72.7 \% \\
\text { Pregnancy rate }\end{array}$ & 15 & 4 (including 1 killed fetus) \\
\hline
\end{tabular}

\section{A}

\section{Wild type}

164165166167168169170171172173174175176177178179180 $\frac{\mathrm{gtc}}{\mathrm{V}} \frac{\mathrm{atc}}{\mathrm{I}} \frac{\mathrm{ttt}}{\mathrm{F}} \frac{\mathrm{tac}}{\mathrm{Y}} \frac{\mathrm{atc}}{\mathrm{I}} \frac{\mathrm{atg}}{\mathrm{M}} \frac{\mathrm{gtg}}{\mathrm{V}} \frac{\mathrm{gat}}{\mathrm{D}} \frac{\mathrm{gat}}{\mathrm{D}} \frac{\mathrm{atc}}{\mathrm{I}} \frac{\mathrm{tcc}}{\mathrm{S}} \frac{\mathrm{agg}}{\mathrm{R}} \frac{\mathrm{atg}}{\mathrm{M}} \frac{\mathrm{cct}}{\mathrm{P}} \frac{\mathrm{ttg}}{\mathrm{L}} \frac{\mathrm{ata}}{\mathrm{I}} \frac{\mathrm{gag}}{\mathrm{E}}$ G12 piglet (Biallelic KO)

164165166167168169170171172173174175176177178 $\frac{\mathrm{gtc}}{\mathrm{V}} \frac{\mathrm{atc}}{\mathrm{I}} \frac{\mathrm{ttt}}{\mathrm{F}} \frac{\mathrm{t} / \mathrm{gg}}{\mathrm{W}} \frac{\mathrm{tgg}}{\mathrm{W}} \frac{\mathrm{atg}}{\mathrm{M}} \frac{\mathrm{ata}}{\mathrm{I}} \frac{\mathrm{tct}}{\mathrm{S}} \frac{\mathrm{cca}}{\mathrm{P}} \frac{\mathrm{gga}}{\mathrm{G}} \frac{\mathrm{tgc}}{\mathrm{C}} \frac{\mathrm{ctt}}{\mathrm{L}} \frac{\mathrm{tga}}{\star} \frac{\mathrm{tag}}{\star} \frac{\mathrm{agc}}{\mathrm{L}}$ G65 piglet (Biallelic KO)

164165166167168169170171172173174175176177178179 $\frac{\mathrm{gtc}}{\mathrm{V}} \frac{\mathrm{atc}}{\mathrm{I}} \frac{\mathrm{ttt}}{\mathrm{F}} \frac{\mathrm{tac}}{\mathrm{Y}} \frac{\mathrm{atc}}{\mathrm{I}} \frac{\mathrm{atg}}{\mathrm{M}} \frac{\mathrm{a} / \mathrm{gg}}{\mathrm{R}} \frac{\mathrm{atg}}{\mathrm{M}} \frac{\mathrm{ata}}{\mathrm{I}} \frac{\mathrm{tct}}{\mathrm{S}} \frac{\mathrm{cca}}{\mathrm{P}} \frac{\mathrm{gga}}{\mathrm{G}} \frac{\mathrm{tgc}}{\mathrm{C}} \frac{\mathrm{ctt}}{\mathrm{L}} \frac{\mathrm{tga}}{\star} \frac{\mathrm{tag}}{\star}$

\section{G3F1 (Biallelic KO)}

164165166167168169170171172173 $\frac{\mathrm{gtc}}{\mathrm{V}} \frac{\mathrm{atc}}{\mathrm{I}} \frac{\mathrm{ttt}}{\mathrm{F}} \frac{\mathrm{tac}}{\mathrm{Y}} \frac{\mathrm{atc}}{\mathrm{I}} \frac{\mathrm{at} / 1 \mathrm{t}}{\mathrm{I}} \frac{\mathrm{gga}}{\mathrm{G}} \frac{\mathrm{tga}}{\star} \frac{\mathrm{tat}}{\mathrm{Y}} \frac{\mathrm{ctc}}{\mathrm{L}}$

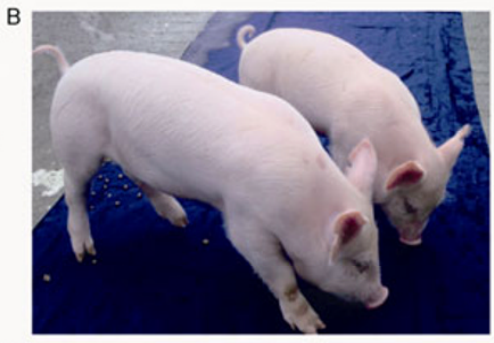

C

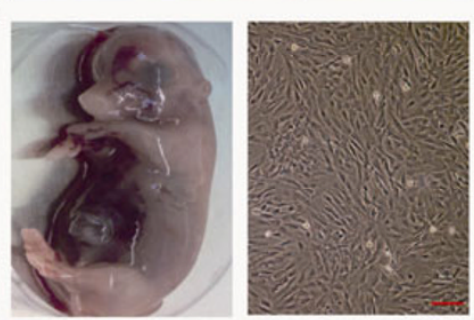

Figure 2 Generation of GGTA1 knockout cloned pigs and primary fibroblasts derived from cloned fetuses. A, DNA and amino acid sequences of GGTA1 proximal to the ZFN targeting site in the biallelic knockout cell clones used for SCNT. The yellow highlighted region indicates the space of the ZFNs. B, Image of GGTA1 null cloned piglets at four weeks of age. C, Primary fibroblasts isolated from the cloned fetus G3F1. Scale bar, $100 \mu \mathrm{L}$. 
G3F9) were obtained, from which primary fibroblasts were successfully isolated and cultured (Figure 2C). Sequencing analysis confirmed G3F1 as a knockout fetus in accordance with the donor cell clone G3 (Figure 2A).

\subsection{Gal epitopes were eliminated in fibroblasts derived from $G G T A 1$ null piglets and fetuses}

Isolectin B4 shows high affinity toward alpha galactose on cell membranes [22,23]. Hence, FITC-conjugated isolectin B4 was used to detect Gal epitopes of GGTA1 mutant porcine cells. In our study, isolectin B4 staining showed the absence of Gal epitopes on G65P2 and G3F1 cells, which were derived from GGTAl null cloned piglets and fetuses, respectively. On the other hand, wild-type primary fibroblasts (11LW5) exhibited obvious green fluorescence on their cell surfaces, indicating Gal epitopes (Figure 3A).

\subsection{GGTA1 biallelic mutation protects porcine fibro- blasts from complement-mediated lysis}

To study whether depletion of Gal epitopes prevents cell lysis by the human complement system, GGTA1 null fibroblasts from cloned piglets (G65P2) and from cloned fetuses (G3F1), as well as wild-type fibroblasts (11LW5), were treated with complete human serum. Trypan blue staining and MTT assays were performed to detect cell survival after immune attack. Trypan blue stains dead cells while MTT assays label live cells. By treating the cells with a $1: 10 \mathrm{di}-$ lution of human serum for $6 \mathrm{~h}, 88.2 \%$ of the wild-type cells were killed. However, the GGTA1 null cells (G65P2 and
G3F1) only showed approximately $18 \%$ cell death (Figure 3B). Similarly, the MTT assays also demonstrated that few 11LW5 cells survived after human serum treatment. On the other hand, GGTA1 null fibroblasts showed nearly full activity, indicated by an accumulation of formazan (Figure $3 \mathrm{C})$. These results convincingly showed that the elimination of Gal epitopes by ZFN-mediated GGTAl knockout efficiently protected pig somatic cells from human complement-mediated lysis.

\section{Discussion}

In this study, we demonstrated that ZFN technology was capable of efficiently disrupting GGTAl gene in porcine somatic cells. Moreover, biallelic knockout piglets were successfully produced via SCNT using ZFN-targeted cells. Fibroblasts derived from GGTA1 null cloned piglets and fetuses lacked Gal epitopes and showed dramatic resistance against human complement-mediated lysis, as described in previous reports.

Due to their physiological and anatomical similarities with humans, pigs are considered to be a better experimental model than rodents and one of the best donors for organ transplantation. However, precise genetic modification of pigs is quite difficult due to the absence of ES cells, which dramatically hampers the use of pigs in biomedical research and drug discovery. In our current study, we demonstrated that ZFN-mediated targeting has an efficiency 10000-fold higher than that of conventional HR targeting technology. Furthermore, biallelic knockout could be achieved in primary cells with a frequency of $5.2 \%$, which
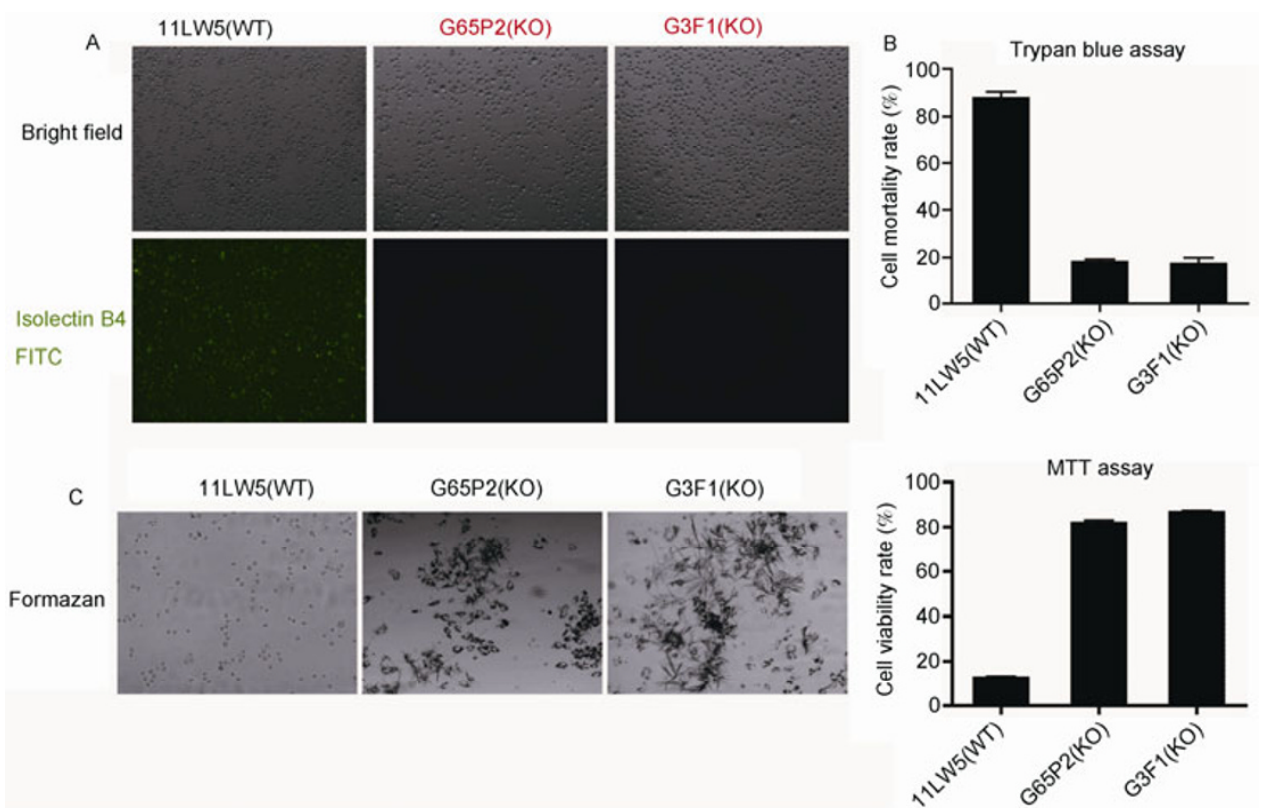

Figure 3 Gal epitope detection and complement-mediated lysis of porcine ZFN-GGTA1 knockout fibroblasts. A, Isolectin B4-FITC-staining of fibroblasts from wild-type pigs, knockout cloned piglets and fetuses. B, Trypan blue assay of GGTA1 knockout fibroblasts treated with human serum. C, MTT assay of GGTA1 knockout fibroblasts treated with human serum. 11LW5 is a wild-type porcine fibroblast line, while G65P2 and G3F1 are fibroblasts derived from GGTA1 knockout cloned piglets and fetuses, respectively. 
means that genetically deficient pigs could be generated from a single cloning step. During the process of our study, similar progress had been made by other groups, who also demonstrated the efficient generation of ZFN-mediated GGTAl knockout pigs via SCNT [24,25].

Previous studies found that GGTAl knockout reduced immune rejection, but this strategy could not completely eliminate immune rejection in xenotransplantation. Several improvements have been made to prolong xenograft survival, such as ectopic expression of human complement regulatory proteins (CD46, CD55, or CD59). Because of their limited proliferation ability, genetically modified pig primary cells are difficult to expand for further genetic manipulation. In the current study, we isolated primary fibroblasts from GGTAl null fetuses. These cells allowed additional genetic modification based on GGTAl knockout and improved our understanding of pig-to-human organ transplantation.

This work was supported by grants from Ministry of Science and Technology of China (2011CBA01001, 2012AA020503), the National Science Fund for Distinguished Young Scholars (31025016), the National Natural Science Foundation of China (31271577), Novel Agricultural Variety Breeding Project of Zhejiang Province (2012C12906-8), the Fundamental Research Funds for the Central Universities, the Key Construction Program of the National "985" Project (118000+193411801/006), and the Research Fund for the Doctoral Program of Higher Education of China (20120101110089).

1 Niemann H, Kues WA. Application of transgenesis in livestock for agriculture and biomedicine. Anim Reprod Sci, 2003, 79: 291-317

2 Kuwaki K, Tseng YL, Dor FJ, Shimizu A, Houser SL, Sanderson TM, Lancos CJ, Prabharasuth DD, Cheng J, Moran K, Hisashi Y, Mueller N, Yamada K, Greenstein JL, Hawley RJ, Patience C, Awwad M, Fishman JA, Robson SC, Schuurman HJ, Sachs DH, Cooper DK. Heart transplantation in baboons using $\alpha 1,3$-galactosyltransferase gene-knockout pigs as donors: initial experience. Nat Med, 2005, 11: 29-31

3 Rogers CS, Stoltz DA, Meyerholz DK, Ostedgaard LS, Rokhlina T, Taft PJ, Rogan MP, Pezzulo AA, Karp PH, Itani OA, Kabel AC, Wohlford-Lenane CL, Davis GJ, Hanfland RA, Smith TL, Samuel M, Wax D, Murphy CN, Rieke A, Whitworth K, Uc A, Starner TD, Brogden KA, Shilyansky J, McCray PB Jr, Zabner J, Prather RS, Welsh MJ. Disruption of the CFTR gene produces a model of cystic fibrosis in newborn pigs. Science, 2008, 321: 1837-1841

4 Yamada K, Yazawa K, Shimizu A, Iwanaga T, Hisashi Y, Nuhn M, O'Malley P, Nobori S, Vagefi PA, Patience C, Fishman J, Cooper DK, Hawley RJ, Greenstein J, Schuurman HJ, Awwad M, Sykes M, Sachs DH. Marked prolongation of porcine renal xenograft survival in baboons through the use of $\alpha 1,3$-galactosyltransferase gene-knockout donors and the cotransplantation of vascularized thymic tissue. Nat Med, 2005, 11: 32-34

5 Capecchi MR. Altering the genome by homologous recombination. Science, 1989, 244: 1288-1292

6 Thomas KR, Capecchi MR. Site-directed mutagenesis by gene targeting in mouse embryo-derived stem cells. Cell, 1987, 51: 503-512

7 Jin DI, Lee SH, Choi JH, Lee JS, Lee JE, Park KW, Seo JS. Targeting efficiency of $\alpha$-1,3-galactosyl transferase gene in pig fetal fibroblast cells. Exp Mol Med, 2003, 35: 572-577

8 Lai L, Kolber-Simonds D, Park KW, Cheong HT, Greenstein JL, Im GS, Samuel M, Bonk A, Rieke A, Day BN, Murphy CN, Carter DB, Hawley RJ, Prather RS. Production of $\alpha$-1,3-galactosyltransferase knockout pigs by nuclear transfer cloning. Science, 2002, 295: 1089-1092

9 Hendricks SP, He P, Stults CL, Macher BA. Regulation of the expression of Gal alpha 1-3Gal beta 1-4GlcNAc glycosphingolipids in kidney. J Biol Chem, 1990, 265: 17621-17626

10 Cooper DK, Koren E, Oriol R. Genetically engineered pigs. Lancet, 1993, 342: 682-683

11 Galili U. The $\alpha$-gal epitope (Gal $\alpha 1-3 \mathrm{Gal} \beta 1-4 \mathrm{GlcNAc}-\mathrm{R}$ ) in xenotransplantation. Biochimie, 2001, 83: 557-563

12 Good AH, Cooper DK, Malcolm AJ, Ippolito RM, Koren E, Neethling FA, Ye Y, Zuhdi N, Lamontagne LR. Identification of carbohydrate structures that bind human antiporcine antibodies: implications for discordant xenografting in humans. Transplant Proc, 1992, 24: 559-562

13 Phelps CJ, Koike C, Vaught TD, Boone J, Wells KD, Chen SH, Ball S, Specht SM, Polejaeva IA, Monahan JA, Jobst PM, Sharma SB, Lamborn AE, Garst AS, Moore M, Demetris AJ, Rudert WA, Bottino R, Bertera S, Trucco M, Starzl TE, Dai Y, Ayares DL. Production of a1,3-galactosyltransferase-deficient pigs. Science, 2003, 299: 411414

14 Wu Z, Chen J, Ren J, Bao L, Liao J, Cui C, Rao L, Li H, Gu Y, Dai $\mathrm{H}$, Zhu H, Teng X, Cheng L, Xiao L. Generation of pig induced pluripotent stem cells with a drug-inducible system. J Mol Cell Biol, 2009, 1: 46-54

15 Ross JW, Whyte JJ, Zhao J, Samuel M, Wells KD, Prather RS. Optimization of square-wave electroporation for transfection of porcine fetal fibroblasts. Transgenic research, 2010, 19: 611-620

16 Petersen B, Lucas-Hahn A, Oropeza M, Hornen N, Lemme E, Hassel P, Queisser AL, Niemann H. Development and validation of a highly efficient protocol of porcine somatic cloning using preovulatory embryo transfer in peripubertal gilts. Cloning Stem Cells, 2008, 10: 355-362

17 Onishi A, Iwamoto M, Akita T, Mikawa S, Takeda K, Awata T, Hanada H, Perry AC. Pig cloning by microinjection of fetal fibroblast nuclei. Science, 2000, 289: 1188-1190

18 Chen G, Sun H, Yang H, Kubelik D, Garcia B, Luo Y, Xiang Y, Qian A, Copeman L, Liu W, Cardella CJ, Wang W, Xiong Y, Wall W, White DJ, Zhong R. The role of anti-non-gal antibodies in the development of acute humoral xenograft rejection of hdaf transgenic porcine kidneys in baboons receiving anti-gal antibody neutralization therapy. Transplantation, 2006, 81: 273-283

19 Diamond LE, Quinn CM, Martin MJ, Lawson J, Platt JL, Logan JS. A human CD46 transgenic pig model system for the study of discordant xenotransplantation. Transplantation, 2001, 71: 132-142

20 McCurry KR, Kooyman DL, Alvarado CG, Cotterell AH, Martin MJ, Logan JS, Platt JL. Human complement regulatory proteins protect swine-to-primate cardiac xenografts from humoral injury. Nat Med, 1995, 1: 423-427

21 McGregor CG, Teotia SS, Byrne GW, Michaels MG, Risdahl JM, Schirmer JM, Tazelaar HD, Walker RC, Logan JS. Cardiac xenotransplantation: progress toward the clinic. Transplantation, 2004, 78: 1569-1575

22 Fujimura T, Takahagi Y, Shigehisa T, Nagashima H, Miyagawa S, Shirakura R, Murakami H. Production of $\alpha 1$,3-galactosyltransferase gene-deficient pigs by somatic cell nuclear transfer: a novel selection method for gal $\alpha 1,3-G a l$ antigen-deficient cells. Mol Reprod Dev, 2008, 75: 1372-1378

23 Kirkeby S, Moe D. Binding of Griffonia simplicifolia 1 isolectin B4 (GS1 B4) to $\alpha$-galactose antigens. Immunol Cell Biol, 2001, 79: 121-127

24 Hauschild J, Petersen B, Santiago Y, Queisser AL, Carnwath JW, Lucas-Hahn A, Zhang L, Meng X, Gregory PD, Schwinzer R, Cost GJ, Niemann H. Efficient generation of a biallelic knockout in pigs using zinc-finger nucleases. Proc Natl Acad Sci USA, 2011, 108: 12013-12017

25 Li P, Estrada JL, Burlak C, Tector AJ. Biallelic knockout of the $\alpha-1,3$ galactosyltransferase gene in porcine liver-derived cells using zinc finger nucleases. J Surg Res, 2013, 181: e39-45

Open Access This article is distributed under the terms of the Creative Commons Attribution License which permits any use, distribution, and reproduction in any medium, provided the original author(s) and source are credited. 